\title{
Role of health-related quality of life measures in the routine care of people with multiple sclerosis
} Alessandra Solari*

\author{
Address: Epidemiology Unit, National Neurological Institute C. Besta, Via Celoria 11, 20133 Milan, Italy \\ Email: Alessandra Solari* - solari@istituto-besta.it \\ * Corresponding author
}

Published: 18 March 2005

Health and Quality of Life Outcomes 2005, 3:16 doi:10.1186/1477-7525-3-16

This article is available from: http://www.hqlo.com/content/3/1/16

(c) 2005 Solari; licensee BioMed Central Ltd.

This is an Open Access article distributed under the terms of the Creative Commons Attribution License (http://creativecommons.org/licenses/by/2.0), which permits unrestricted use, distribution, and reproduction in any medium, provided the original work is properly cited.
Received: 07 February 2005

Accepted: 18 March 2005

\begin{abstract}
Health-related quality of life instruments are expected to be of particular value in routine care of people with multiple sclerosis (MS), where they may facilitate the detection of disease aspects that would otherwise go unrecognised, help clinicians appreciate patient priorities particularly in terms of treatment goals, facilitate physician-patient communication, and promote shared decisionmaking. However, it appears that these instruments are little used routine clinical approaches to people with MS. To address this issue, I performed a bibliographic search of studies that evaluated the efficacy of generic or disease-specific health-related quality of life (HRQOL) instruments in MS clinical practice from clinicians' or patients' perspectives. I found only one cross-sectional study, which compared preferences for three instruments, and assessed acceptability in people with MS.

Reasons for lack of transfer of HRQOL measurements to clinical practice may be cultural, methodological, or practical. With regard to $\mathrm{MS}$, the proliferation of instruments seems to constitute a barrier, with no particular instrument having gained wide popularity or consensus. Other barriers are lack of resources for the administration, collection and storage of the data, and inability of clinicians to score, interpret, and use HRQOL instrument to guide clinical care. It is therefore important to refine existing tools, extending clinical validation to wider contexts and cultures. More studies assessing acceptability and clinicians' and patients' preferences for different instruments are also required.
\end{abstract}

\section{Review}

Multiple sclerosis (MS) is a demyelinating disease of the central nervous system of unknown etiology and poorly understood pathogenesis. There is a north-south gradient of MS prevalence in the northern hemisphere, with highest levels (over 100 per 100,000) in northern regions $[1,2]$. It is a chronic disease with a modest effect on life expectancy, but a broad spectrum of consequences, of variable severity, on physical and psychological characteris- tics, that vary between individuals and within individuals over time. The disease typically strikes women $(2: 1)$ in their peak years of career development and family life; commonly there are exacerbations and remissions followed by progression whose rate and extent vary [3]. There is also a benign form of MS, characterised by few relapses, long periods of remission, and mild activity limitations over the long term [4]. The available treatments 
Table I: Characteristics of MS-specific HRQOL questionnaires

\begin{tabular}{|c|c|c|c|c|c|c|c|}
\hline & MSQOL-54 & FAMS & MSQLI & RAYS & HAQUAMS & MSIS-29 & LMSQoL \\
\hline Publication year & 1995 & 1996 & 1999 & 2000 & 2001 & 2001 & 2001 \\
\hline Generic module & SF-36 (36 items) & FACT-G (28 items) & SF-36 (36 items) & -- & -- & -- & -- \\
\hline MS module & 18 items & 31 items & 9 scales & 50 items & 38 items & 29 items & 8 items \\
\hline $\begin{array}{l}\text { People with MS } \\
\text { involved in } \\
\text { development }\end{array}$ & No & Yes & -- & No & MYes & Yes & Yes \\
\hline Versions & $\begin{array}{c}\text { US English [13] } \\
\text { Italian [20] } \\
\text { French [2I] } \\
\text { Canadian French [22] } \\
\text { Japanese [23] }\end{array}$ & $\begin{array}{l}\text { US English [14] } \\
\text { Portuguese [24] }\end{array}$ & US English [15] & Hebrew [16] & German [17] & English [18] & English [19] \\
\hline Reliability & $\begin{array}{c}\text { Alpha Test-retest } \\
{[13,20-23]}\end{array}$ & Alpha $[14,24]$ & $\begin{array}{c}\text { Alpha Test-retest } \\
\text { [15] }\end{array}$ & Alpha [16] & $\begin{array}{c}\text { Alpha Test-retest } \\
\text { [17] }\end{array}$ & $\begin{array}{c}\text { Alpha Test-retest } \\
{[18]}\end{array}$ & $\begin{array}{c}\text { Alpha Test-retest } \\
{[19]}\end{array}$ \\
\hline Responsiveness & $\begin{array}{l}\mathrm{RCT}[25] \\
\mathrm{RCT}[26]\end{array}$ & -- & RCT [27] & -- & $\mathrm{RCT}[28]$ & Effect size [18] & -- \\
\hline $\begin{array}{l}\text { Domains not } \\
\text { assessed }\end{array}$ & Vision & $\begin{array}{l}\quad \text { Vision } \\
\text { Bladder/ bowel } \\
\text { Sexual function }\end{array}$ & -- & -- & -- & $\begin{array}{c}\text { Vision } \\
\text { Sexual function }\end{array}$ & Vision \\
\hline $\begin{array}{l}\text { Time period } \\
\text { assessed }\end{array}$ & $\begin{array}{l}\text { Past } 4 \text { weeks } \\
\text { Current time }\end{array}$ & Past week & -- & Past week & $\begin{array}{c}\text { Past year } \\
\text { Past } 4 \text { weeks } \\
\text { Past week }\end{array}$ & Past 2 weeks & Past month \\
\hline Time to complete & 20 minutes & 20 minutes & -- & -- & 20 minutes & -- & -- \\
\hline Publications (no.) & 16 & 10 & 5 & 1 & 3 & 7 & 2 \\
\hline Publication period & 1995-2004 & 1996-2004 & 1999-2003 & 2000 & $200 \mathrm{I}-2004$ & $200 I-2004$ & 2001 \\
\hline
\end{tabular}

MSQOL-54 is the MS quality-of-life 54; FAMS is the Functional Assessment of MS; MSQLI is the MS Quality of Life; HAQUAMS is the Hamburg Quality of Life Questionnaire in MS; FACT-G is the Functional Assessment of Cancer Therapy, General version; LMSQoL is the Leeds MS Quality of Life. Alpha is Cronbach's coefficient alpha. RCT aspects of responsiveness assessed in randomized controlled trial.

have at best a modest benefit on the course of the disease [5].

\section{Health-related quality of life measures}

Interest in measuring outcomes in MS has increased markedly over the past 20 years. Standardised instruments have been developed, the most-used being the Expanded Disability Status Scale (EDSS) [6] which is a mixed impairment/activity limitations scale based on neurological examination of eight functional systems, plus ambulation/mobility status. Despite major limitations - bias towards locomotor function, variable sensitivity to change according to scale score, and suboptimal interrater reliability - the EDSS is widely-used by researchers and clinicians because its scores are readily understood by all.

More recently, the importance of MS outcome assessment from the perspective of the person with the disease has been recognised [7]. After 1992, the number of publications on health-related quality of life (HRQOL) increased steadily, as did those employing MS-specific instruments (see Figure). Generic instruments were applied to MS [7$12]$, and disease-specific instruments were devised and validated [13-24]. The seven available MS-specific HRQOL instruments are listed in the Table 1; all were published between 1995 and 2001. Three consist of a generic module (SF-36 [13,15] or FACT-G [14]) plus an MS-specific module. In most cases people with MS participated in their development $[13,16]$. Except for the MS
Quality of Life 54 (MSQOL-54), which has been translated into several languages [13,20-23], and the Functional Assessment of MS (FAMS), which is also available in Portuguese [24], these questionnaires are available only their original versions. Aspects of responsiveness were evaluated in four of the seven instruments, but in general sensitivity to change has been insufficiently investigated $[18,25-28]$

\section{HRQOL and routine clinical practice}

HRQOL studies in MS have drawn attention to the multiplicity of domains that may be compromised by the disease, and the effects of this compromise on ability to cope. As expected, people with MS, especially those with a progressive course, report reduced physical functioning compared to the general population $[10,11,29-31]$; they are more likely to suffer fatigue [29,32] and depression $[32,33]$ than the general population, and are also more likely to be unemployed $[8,10,30,31,34,35]$. Unexpectedly, however, it has been reported that the importance attached to compromise in different HRQOL domains may vary considerably between MS sufferers and their neurologists [7].

The ultimate aim of measuring HRQOL is to provide a comprehensive assessment of patients' health status, to serve as a baseline from which to tailor interventions, pharmacological or otherwise, and assess their effectiveness, both in the clinical trial setting and in routine care. HRQOL instruments are expected to be of particular value 
in routine care, where they may improve the detection of disease aspects that would otherwise go unrecognised, help clinicians appreciate patient priorities particularly in terms of treatment goals, facilitate physician-patient communication, and promote shared decision making. In addition HRQOL data from clinical trials can provide information that clinicians can usefully discuss with their patients [36]. Unfortunately, although recent MS trials include some HRQOL assessment, there is no internationally agreed gold standard for conducting such assessment or reporting outcomes. HRQOL evaluations are not required as endpoints in MS trials by the European Agency for the Evaluation of Medicinal Products [37]. Even when HRQOL endpoints are included, data collection and reporting are often of poor quality [38] with the consequence that cost effectiveness issues, which HRQOL instruments can throw light on, such as preserved function, less work missed, and improved emotional wellbeing, are not analysed.

\section{Literature survey}

It appears that HRQOL instruments are little used in routine clinical approaches to people with MS. To address this issue, I searched MEDLINE (1966-2004), the Cochrane Library (Issue 1, 2005) and the Cochrane MS Group trials register (2004) for studies that evaluated the efficacy of generic or MS-specific HRQOL instruments in clinical practice from the clinicians' or MS patients' perspective, also checking study references. Studies considering patient-reported outcomes other than HRQOL, and domain-specific measures were excluded.

I found only one study, a cross-sectional postal survey conducted in Canada, published in 2004 [39]. This study assessed MS sufferers' preferences regarding two generic instruments (the EuroQol EQ-5D and the SF-36), and an MS-specific instrument (MSQOL-54). Over $90 \%$ of 183 participants reported that EuroQol EQ-5D and the SF-36 were acceptable or very acceptable, and $85 \%$ did so for MSQOL-54. Surprisingly, over $75 \%$ of participants felt that a combination of the three instruments best described their HRQOL.

The reasons for lack of transfer of HRQOL assessment into clinical practice may be cultural, practical, or methodological [40-43]. With regard to cultural factors, patients generally welcome the opportunity to provide clinicians with information regarding their HRQOL [43]. That this is also the case for people with MS is suggested by high participation rates in most postal surveys assessing patientreported health status $[30,35,39,44]$, and by the good acceptability of HRQOL instruments [39]. By contrast, information on practicing clinicians' perceptions of the utility of HRQOL data is limited and conflicting: studies have uncovered a lack of knowledge of HRQOL as well as concerns that these instruments may be a covert means of assessing physicians' performance $[45,46]$.

Practical considerations be particularly important in clinical settings, where data must be provided promptly and in an understandable manner to be of use. Instruments must be administered, processed, scored, stored and retrieved - all of which have logistic and financial implications [47]. Most HRQOL instruments are lengthy and may be burdensome for patients and clinicians. For most existing instruments, the score is not immediately available, but needs to be calculated, while score interpretation may not be straightforward. For example a recently published study on transplant physicians found that 55\% would be more likely to use HRQOL data if it were more comprehensible [48]. In the United States time spent gathering and interpreting HRQOL information as part of the clinical encounter is not built into reimbursement by third-party payers [49]. It is noteworthy, however, that questionnaire length seems not to be a drawback for people with MS since a combination of HRQOL instruments was preferred by over $75 \%$ of participants in the only study found [39].

Another factor limiting the dissemination of HRQOL tools in MS clinical practice is likely to be that too many instruments are available, and unlike EDSS, none has emerged as clearly superior to any other.

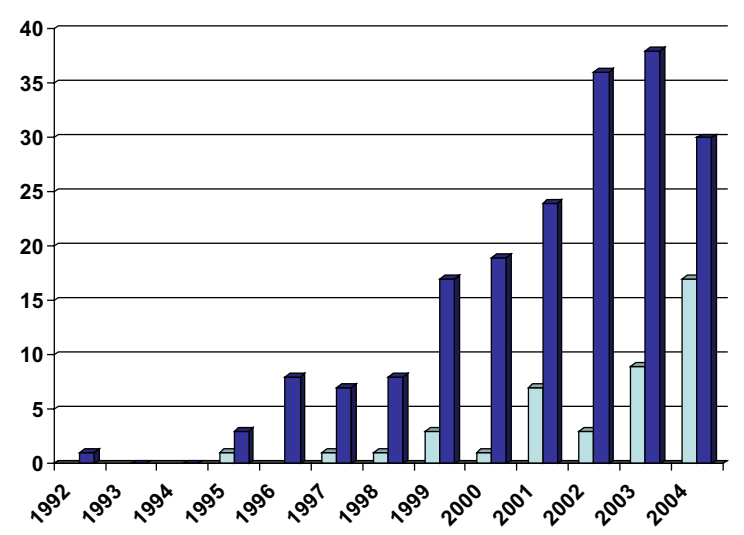

\section{Figure I}

Number of publications on HRQOL in people with MS between 1992 and 2004. Blue bars indicate all studies on HRQOL; light blue bars indicate studies employing MS-specific instruments. Studies considering patient-reported outcomes other than HRQOL, or domain-specific measures are excluded. 


\section{Conclusion}

Existing HRQOL tools for people with MS should be refined and their clinical validation pursued in the widest possible cultural context. More studies assessing instrument acceptability and preferences of clinicians and people with MS are also needed. It would be useful for example to implement computer-based technology (touch-screens and adaptive administration to reduce respondent burden by selecting pertinent items and omitting inappropriate ones) and other alternatives to traditional paper-and-pencil or interview methods, which should of course be evaluated for acceptability and reliability [48]. The objective is not to add HRQOL measurements to the chores of everyday practice, but to incorporate meaningful HRQOL instruments into the care process [50].

\section{Acknowledgements}

I am indebted to Dr. Barbara Vickrey and Dr. Christoph Heesen for their helpful suggestions for improving the manuscript. Thanks are also due to Dr. Maura Moggia, trial search coordinator of the Cochrane MS Group, for providing the search strategy, and to Mrs. Giusi Ferrari for retrieving the studies, and to Don Ward for help with the English.

\section{References}

I. Compston A: Genetic epidemiology of multiple sclerosis. J Neurol Neurosurg Psychiatry 1997, 62:553-56I.

2. Kurtzke JF: Geography in multiple sclerosis. J Neurol 1977, 215:1-26.

3. Sadovnick AD, Ebers GC: Epidemiology of multiple sclerosis: a critical overview. Can J Neurol Sci 1993, 20:17-29.

4. Pittock SJ, McClelland RL, Mayr WT, Jorgesten NW, Weinshenker BG, Noseworthy J, Rodriguez M: Clinical implications of benign multiple sclerosis: A 20-year population-based follow-up study. Ann Neurol 2004, 56:303-306.

5. Filippini G, Munari L, Incorvaia B: Interferons in relapsing remitting multiple sclerosis: a systematic review. Lancet 2003, 36 I:545-552.

6. Kurtzke JF: Rating neurologic impairment in multiple sclerosis: an expanded disability status scale. Neurology 1983, 33: 1444-1452

7. Rothwell PM, McDowell Z, Wong CK, Dorman PJ: Doctors and patients don't agree: cross sectional study of patients and doctors perceptions and assessments of disability in multiple sclerosis. BM] 1997, 3 14:1580-I583.

8. Aronson KJ: Quality of life among persons with multiple sclerosis and their caregivers. Neurology 1997, 48:74-80.

9. Brunet DG, Hopman WM, Singer MA, Edgar CM, MacKenzie TA: Measurement of health-related quality of life in multiple sclerosis patients. Can J Neurol Sci 1996, 23:99-103.

10. Burden of illness of multiple sclerosis: Part II: Quality of life. The Canadian Burden of Illness Study Group. Can J Neurol Sci 1998, 25:3I-38.

11. Pfennings LEMA, Cohen L, Van der Ploeg HM: Assessing the quality of life in patients with multiple sclerosis. In Multiple sclerosis: clinical changes and controversies Edited by: Thompson AJ, Polman C, Hohlfeld R. London: Martin Dunitz; 1997.

12. Lintern TC, Beaumont G, Kenealy PM, Murrell RC: Quality of life (QoL) in severely disabled multiple sclerosis patients: Comparison of three QoL measures using multidimensional scaling. Qual Life Res 200I, 10:37I-378.

13. Vickrey BG, Hays RD, Harooni R, Myers LW, Ellison GW: A healthrelated quality of life measure for multiple sclerosis. Qual Life Res 1995, 4: 187-206.

14. Cella DF, Dineen MA, Arnason B, Reder A, Webster KA, karabatsos G, Chang C, Lloyd S, Steward J, Stefoski D: Validation of the Functional Assessment of Multiple Sclerosis quality of life instrument. Neurology 1996, 47:129-139.
15. Fischer JS, LaRocca NG, Miller DM, Ritvo PG, Andrews H, Paty D: Recent developments in the assessment of quality of life in multiple sclerosis (MS). Mult Scler 1999, 5:25I-259.

16. Rotstein Z, Barak Y, Noy S, Achiron A: Quality of life in multiple sclerosis: development and validation of the "RAYS" scale and comparison with the SF-36. Int J Qual Health Care 2000, I 2:51|-5|7.

17. Gold SM, Heesen C, Schulz H, Guder U, Monch A, Gbadamosi J, Buhmann C, Schulz KH: Disease-specific quality of life instruments in multiple sclerosis: validation of the Hamburg Quality of Life Questionnaire in multiple sclerosis (HAQUAMS). Mult Scler 200I, 7:119-130.

18. Hobart JC, Lamping DL, Fitzpatrick R, Riazi A, Thompson A: The Multiple Sclerosis Impact Scale (MSIS-29): a new patientbased outcome measure. Brain 200I, I 24:962-973.

19. Ford HL, Gerry E, Tennant A, Whalley D, Haigh R, Johnson MH: Developing a disease-specific quality of life measure for people with multiple sclerosis. Clin Rehabil 200I, 15:247-258.

20. Solari A, Filippini G, Mendozzi L, Grezzi A, Cifani S, Barbieri E, Baldini S, Salmeggi A, LaMantia L, Farinotti M, Caputo D, Mosconi P: Validation of Italian multiple sclerosis quality of life 54 questionnaire. J Neurol Neurosurg Psychiatry 1999, 67: 158-162.

21. Vernay D, Gerbaud L, Biolay S, Coste J, Debourse I, Aufauvre D, Beneton C, Colamarino R, Glandier PY, Dordain G, Clavelou P: Quality of life and multiple sclerosis: validation of the French version of the self-questionnaire (SEP-59). Rev Neur 2000, 156:247-263.

22. Acquadro C, Lafortune L, Mear I: Quality of life in multiple sclerosis: translation in French Canadian of the MSQoL-54. Health Qual Life Outcomes 2003, 1:70.

23. Yamamoto T, Ogata K, Katagishi M, Shimizu H, Ogawa M, Yamamura T, Kawai M: Validation of the Japanese-translated version Multiple Sclerosis Quality of Life-54 instrument. Rinsho Shinkeigaku 2004, 44:417-421.

24. Mendes MF, Balsimelli S, Stangehaus G, Tilbery CP: Validation of the functional assessment of multiple sclerosis quality of life instrument in a Portuguese language. Arq Neuropsiquiatr 2004, 62:108-II3

25. Lincoln NB, Dent A, Harding J, Weyman N, Nicholl C, Blumhardt LD, Playford ED: Evaluation of cognitive assessment and cognitive intervention for people with multiple sclerosis. J Neurol Neurosurg Psychiatry 2002, 72:93-98.

26. Solari A, Motta A, Mendozzi L, Pucci E, Forni M, Mancardi G, Pozzilli $C$ : Computer-aided retraining of memory and attention in people with multiple sclerosis: a randomized, double-blind controlled trial. J Neurol Sci 2004, 222:99-104.

27. Cohen JA, Cutter GR, Fischer JS, Goodman AD, Heidenreich FR, Kooijmans MF, Sandrock AW, Rudick RA, Simon JH, Simonian NA, Tsao EC, Whitaker JN: Benefit of interferon $\beta$ - I a on MSFC progression in secondary progressive MS. Neurology 2002, 59:679-687.

28. Schulz KH, Gold SM, Witte J, Bartsch K, Lang UE, Hellweg R, Reer R, Braumann KM, Heesen C: Impact of aerobic training on immune-endocrine parameters, neutrophic factors, quality of life and coordinative function in multiple sclerosis. J Neurol Sci 2004, 225: I I-I8.

29. Lobentanz IS, Asenbaum S, Vass K, Sauter C, Klösch G, Kollegger H, Kristoferitsch W, Zeitlhofer J: Factors influencing quality of life in multiple sclerosis patients: disability, depressive mood, fatigue and sleep quality. Acta Neurol Scand 2004, I I 0:6-13.

30. Solari A, Radice D: Health status of people with multiple sclerosis: a community mail survey. Neurol Sci 200I, 22:307-3I5.

31. Henriksson F, Fredrikson S, Masterman T, Jönsson : Costs, quality of life and disease severity in multiple sclerosis: a cross-sectional study in Sweden. Eur J Neurol 200I, 8:27-35.

32. Amato MP, Ponziani G, Rossi F, Liedl CL, Stefanile C, Rossi L: Quality of life in multiple sclerosis: the impact of depression, fatigue, and disability. Mult Scler 200I, 7:340-344.

33. Wang JL, Reimer MA, Metz LM, Patten SB: Major depression and quality of life in individuals with multiple sclerosis. Int J Psychiatry Med 2000, 30:309-3I7.

34. Grønning M, Hannisdal E, Mellgren SI: Multivariate analyses of factors associated with unemployment in people with multiple sclerosis. J Neurol Neurosurg Psychiatry 1990, 53:388-390. 
35. Ford HL, Gerry E, Johnson MH, Tennant A: Health status and quality of life measure of people with multiple sclerosis. Disabil Rehabil 200I, 23:516-52I.

36. Vickrey BG: Getting oriented to patient-oriented outcomes. Neurology 1999, 53:662-663.

37. Note for guidance on clinical investigation of medicinal products for the treatment of multiple sclerosis [http:// www.emea.eu.int/pdfs/human/ewp/056198en.pdf]. last accessed March 2005

38. Moher D, Schulz KF, Altman DG: The CONSORT statement: revised recommendations for improving the quality of reports of parallel-group randomised trials. Lancet 200I, 357:1191-1194.

39. Moore F, Wolfson C, Alexandrov L, Lapierre Y: Do general and multiple sclerosis- specific quality of life instruments differ? Can J Neurol Sci 2004, 3 I:64-7I.

40. Deyo RA, Patrick DL: Barriers to the use of health status measures in clinical investigation, patient care, and policy research. Med Care 1989, 27:S252-S268

4I. McHorney CA, Taylor AR: Individual-patient monitoring in clinical practice: are available health status surveys adequate? Qual Life Res 1995, 4:293-307.

42. Rubenstein LV, McCoy JM, Cope DW, Barrett PA, Hirsch SH, Messer KS, Young RT: Improving patient quality of life with feedback to physicians about functional status. J Gen Intern Med 1995, 10:607-614

43. Nelson EC, Landgraf JM, Hays RD, Wasson JH, Kirk JW: The functional status of patients: how can it be measured in physician's offices? Med Care 1990, 28: IIII-II 26.

44. Somerset M, Campbell R, Sharp DJ, Peters T: What do people with MS want and expect from health-care services? Health Expectations 200I, 4:29-37.

45. Kazis LE, Callahan LF, Meenan RF, Pincus TSO: Health status reports in the care of patients with rheumatoid arthritis. J Clin Epidemiol 1990, 43: I 243-I253.

46. Wagner AK, Ehrenberg BL, Tran TA, Bungay KM, Cynn DJ, Rogers WH: Patient-based health status measurement in clinical practice: a study of its impact on epilepsy patients' care. Qual Life Res 1997, 6:329-34I.

47. Gilbody SM, House AO, Sheldon TA: Psychiatrists in the UK do not use outcomes measures. National survey. $\mathrm{Br} J$ Psychiatry 2002, I 80: $101-103$.

48. Lee SJ, Joffe S, Kim HT, Socie G, Gilman AL, Wingard JR, Horowitz MM, Cella D, Syrjala KL: Physicians' attitudes about quality of life issues in haematopoietic stem cell transplantation. Blood 2004, I 04:2194-2200.

49. Donaldson MS: Tacking stock of health-related quality-of-life measurement in oncology practice in the United States. J Natl Cancer Inst Monogr 2004, 33:155-167.

50. Fitzpatrick R, Fletcher A, Gore S, Jones D, Spiegelhalter D, Cox D: Quality of life measures in health care. I: Applications and issues in assessment. BMJ 1992, 305:1074-1077.

\section{Publish with Bio Med Central and every scientist can read your work free of charge}

"BioMed Central will be the most significant development for disseminating the results of biomedical research in our lifetime. "

Sir Paul Nurse, Cancer Research UK

Your research papers will be:

- available free of charge to the entire biomedical community

- peer reviewed and published immediately upon acceptance

- cited in PubMed and archived on PubMed Central

- yours - you keep the copyright 